\title{
SAJÁTOS NEVELÉSI IGÉNYEK ÉS BEFOGADÓ NEVELÉS EURÓPÁBAN
}

\author{
KÁLLAI GABRIELLA* - MILE ANIKÓ \\ ELTE Bárczi Gusztáv Gyógypedagógiai Kar
}

Az elmúlt évtizedekben a nemzetközi megközelítésben használt sajátos nevelési igény fogalma átalakult, kiszélesedett. Ezzel együtt az együttnevelés kezdetben a különböző fogyatékos tanulókra terjedt ki, ma már több csoportot is magába foglal, és a vonatkozó szabályok az Európai Unió tagországaiban is különbözőek. Az uniós célkitűzéseknek megfelelően több ország oktatási rendszerében egyre nagyobb körben van jelen az inklúzió, ami sok elemében hasonló, némely vonatkozásban pedig különböző lehet. A szemléletmód változása hatással van a problémák azonosítására is. Írásunk az európai adatgyüjtés kvalitatív és kvantitatív adatait, valamint a hazai folyamatokat mutatja be.

Kulcsszavakः sajátos nevelési igény, inklúzió, Európa

In recent decades, the concept of special educational needs used in the international literature has changed and expanded. Conceptual approach to inclusion initially covered students with different disabilities, now it includes several other groups, and the relevant regulations also differ from one member state of the European Union to another. In line with EU objectives, inclusion in the education systems of several countries is increasing, which is similar in many aspects and may differ in some other aspects. Changing conceptual approaches also have an impact on problem identification. Our paper gives an overview of qualitative and quantitative data of European data collection, as well as presents the proper Hungarian processes.

Keywords: special educational needs, inclusion, Europe

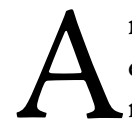

nemzetközi gyakorlatban a második világháború után az emberi jogi mozgalmak előretörése és más társadalmi változások okán az együttnevelés lehetőségének megteremtése és biztosítása került a figyelem fókuszába (lásd füzetünkben Perlusz tanulmánya). A sok országban elkülönítetten müködő gyógypedagógiai iskolarendszer mint ellátási szektor átlépésének gondolata szorosan összefüggött azzal, hogy a nevelési tapasztalatok ráirányították a figyelmet az elkülönített óvodáztatás, iskoláz-

* Levelező szerző: Kállai Gabriella, ELTE BGGYK. E-mail: kallai.gabriella@barczi.elte.hu 
tatás negatív kihatásaira, a szelekciós és szegregációs mechanizmusok hátrányteremtő jellegére (Lányiné Engelmayer 1993, idézi Mile 2016).

A sajátos nevelési igénynek (special educational needs) ${ }^{1}$ mint fogalmi konstrukciónak a nemzetközi színtéren nem egységes a tartalma. Általában az egyes államok jogi szabályozásában rögzítik, időben is módosulhat, ami a számok és arányok változásában is megmutatkozhat. A nemzetközi, így az európai színtéren is országonként igen eltérőek az ellátásra jogosító kritériumok, sőt, egy-egy országon belül a szakpolitikai döntéshozók, gyakorlati szakemberek (pedagógusok, gyógypedagógusok stb.), kutatók és a szélesebb közösség sem minden tekintetben ért egyet abban, hogy kik tekinthetők, és kik nem fogyatékos - vagy szélesebb értelmezésben sajátos nevelési igényü tanulónak. Ennek oka, hogy a speciális nevelési igény mint ellátásra jogosító kategória létrejötte két fő megközelítési módra vezethető vissza: egyrészt okozhatják személyen belüli tényezők, adottságok, a károsodások különféle formái, másrészt a környezetben is léteznek olyan tényezők, melyek ellensúlyozhatják, mérsékelhetik vagy nehezíthetik, súlyosbíthatják az egyéni tanulást, az iskolarendszerben való boldogulást, a társadalmi életbe való beilleszkedést. A különféle, egymást kiegészítő vagy egymásra épülő ellátások, támogatások tervezése és biztosítása érdekében szükséges az érintettek létszámának, arányainak meghatározása. Az első ilyen becslések egyike volt Angliában a Warnock-Bizottság jelentése (1978), mely témánk szempontjából azért is fontos, mert elsőként használta ezen arányok meghatározásánál a „sajátos nevelési igény” fogalmát, kifejezve azt, hogy ezzel a mutatóval nem csupán a fogyatékos gyermekek, tanulók számát vagy arányát határozzák meg, hanem azokét a diákokét összességében, akiknek a speciális nevelési szükségleteit a közoktatásban vagy a speciális intézményrendszerben kell kielégíteni (Lányiné Engelmayer 2009). Jelentős szemléletbeli változás mutatkozik meg ebben a megközelítésben: az addig megszokott és az ellátások alapjául szolgáló merev diagnosztikai kategóriák helyett a gyermek/tanuló nevelési, oktatási szükségletei kerültek előtérbe, elsősorban az eredményesen megvalósítható együttnevelés érdekében. Ezzel összefüggésben azt is ki kell emelnünk, hogy az igénybe vehető szolgáltatások, tárgyi, infrastrukturális feltételek, megfelelő szakemberek megléte és jelenléte mellett kulcsfontosságú az a szemléletmód is, ahogyan a gyermekekkel, tanulókkal foglalkozó szakemberek (elsősorban pedagógusok) és nem mellesleg a társadalom a sajátos nevelési igényü gyermekekre/tanulókra tekint.

Az európai közösségi politikában az 1980-as években jelent meg először a törekvés arra, hogy a társadalmi kohézió, integráció erősítése érdekében megvizsgálják azt is, hogy az egyes tagországokban mi történik a tanulók oktatási integrációjával kapcsolatban, és indultak el az első ilyen irányú kezdeményezések az együttnevelés elősegítésére (Halász 2004). Az Európai Unió országaiban ma sem létezik egységes, általánosan elfogadott „fogyatékosság”, sem pedig „speciális nevelési szükséglet” meghatározás, ebből következően a különböző országok közti adatszintü összehasonlítás vagy az eltérő ellátási formák összehasonlíthatósága is igen nehéz feladatot jelent. A problémával szembesülve az Európai Ügynökség a Sajátos Nevelési Igényü Tanulókért és az Inkluziv Oktatásért (European Agency for Special Needs and Inclusive Education, továbbiakban: Agency) 1999 óta igyekszik a tagállamoktól információkat gyűjteni. A gyakorlatban az adat-

A „special educational needs” kifejezést a magyar szakpolitika sajátos nevelési igényként fordította, így mi is ezt a kifejezést használjuk. 
gyưjtés jelentős módszertani nehézségekkel jár, hiszen a kérdések egy részénél az egyes országokban nem állnak rendelkezésre adatok, információk. Az összehasonlíthatóság érdekében az Európai Ügynökség Inkluziv Oktatás Statisztikai Rendszereit Vizsgáló Projektje (European Agency Statistics on Inclusive Education, EASIE) hozzákezdett a nemzeti szintű adatok gyüjtéséhez, a gyüjtött adatok ún. országos adatszakértőktől származnak. Az adatgyưjtés három fó területre irányul, melyek a következők: a hivatalosan sajátos nevelési igényűvé nyilvánított tanulók intézményi elhelyezése; a többségi oktatáshoz való hozzáférés; valamint a befogadó nevelés-oktatáshoz való hozzáférés. Az EASIE által azonos tematika alapján végzett adatgyüjtések 2014-ben, 2016-ban és 2018-ban zajlottak le. Ezen adatok segítségével mutatjuk be az európai körképet. Arra azonban e tanulmány keretei között nincs módunk, hogy a régebbi, hasonló célú adatgyüjtéseket idősorosan összehasonlítsuk, mivel mind tartalmi, mind módszertani szempontból is jelentős változtatások történtek, és nem szeretnénk, hogy téves következtetéseket vonjon le az Olvasó.

Annak érdekében, hogy mégis adatokat lehessen nyerni a sajátos nevelési igényű tanulók ellátásának formáiról, az Agency államaiban az adatgyüjtés alapjául adott ország saját jogi meghatározását használták fel. Ez természetesen módszertani problémákat is jelent, hiszen az egyes államok jogszabályai/szakpolitikái nem minden esetben tartalmazzák például az inkluzív oktatás és/vagy különnevelés, speciális oktatás fogalmát és annak definícióját. Az országok különféle kategóriarendszerek mentén sorolják be az érintett tanulókat. Ezek a kategóriák a következőket tartalmazhatják: fogyatékosság (érzékszervi, fizikai vagy pszichés), tanulási nehézség, viselkedési problémák, egészségi problémák, szociális hátrány stb. Adott kategóriákba az országok általában azokat a gyerekeket sorolják be, akik valamilyen hivatalos jogi dokumentummal rendelkeznek, de nem mindenhol ragaszkodnak ehhez. Az iskolai nevelés (beiskolázás, tankötelezettség) megkezdésének időpontja és időtartama sem azonos az egyes országokban. Sok ország pedig egyáltalán nem gyüjt adatokat azokról a tanulókról, akik teljesen inkluzív környezetben kapnak támogatást - ezzel összefüggésben az országok jelezték azt is, hogy a hivatalos adatok az ,ismert” (vagyis nyilvántartott) gyermekekre, tanulókra vonatkoznak, de a valóságban ennél nagyobb arányban lehetnek, akik többlettámogatásban részesülnek. Ezek a nehézségek is világosan megmutatják, hogy nem lehet pontosan összehasonlítani sem a hivatalosan sajátos nevelési igényű gyermekek, tanulók számadatait, sem pedig a számukra biztosított különféle nevelési, elhelyezési formákat, feltételeket. Arra azonban van lehetőség, hogy a sajátos nevelési igényü gyermekek, tanulók arányát megvizsgáljuk az iskolába járó populációhoz viszonyítva az egyes államokban, ugyanakkor az adatok összehasonlításánál folyamatosan szem előtt kell tartanunk az adatszolgáltatások hátterében álló, eltérő tartalmú meghatározásokat. Az inkluzív vagy elkülönített körülmények között tanulók aránya kiszámítható az iskolarendszerbe beiratkozott tanulókhoz viszonyítva, ugyanakkor itt sem szabad megfeledkezni arról, hogy az adatok mögött definíciós különbségek lehetnek. Az adatok érdekesek, önmagukban azonban nem adnak képet sem az oktatás minőségéről, sem annak megfeleléséről, ezért a kvalitatív adatok figyelembevétele is rendkívül fontos.

Bár a vizsgált országokban az iskolaköteles korú gyermekek rendszerint tanulói jogviszonnyal rendelkeznek, majdnem minden országban vannak olyanok, akik valamilyen okból nem járnak iskolába / nem iratkoztak be (arányuk átlagosan 1-2\%). Ennek okairól jelenleg nem állnak rendelkezésünkre részletesebb adatok. Magyarországon a nemzeti 
köznevelésről szóló 2011. évi CXC. törvény (a továbbiakban: köznevelési törvény) terjesztette ki a tankötelezettséget minden gyermekre, így azok a súlyosan, halmozottan sérült gyermekek, fiatalok, akik eddig különböző ágazati ellátási formák keretében nevelkedtek, jelenleg iskolába beiratkozott tanulók, akik fejlesztő nevelés-oktatás keretében teljesítik tankötelezettségüket.

Először azt mutatjuk be, milyen arányban találunk SNI tanulókat az egyes országok oktatási rendszereiben (1. ábra). A vizsgált 32 állam átlagos mutatója 2018-ban 4,75\%

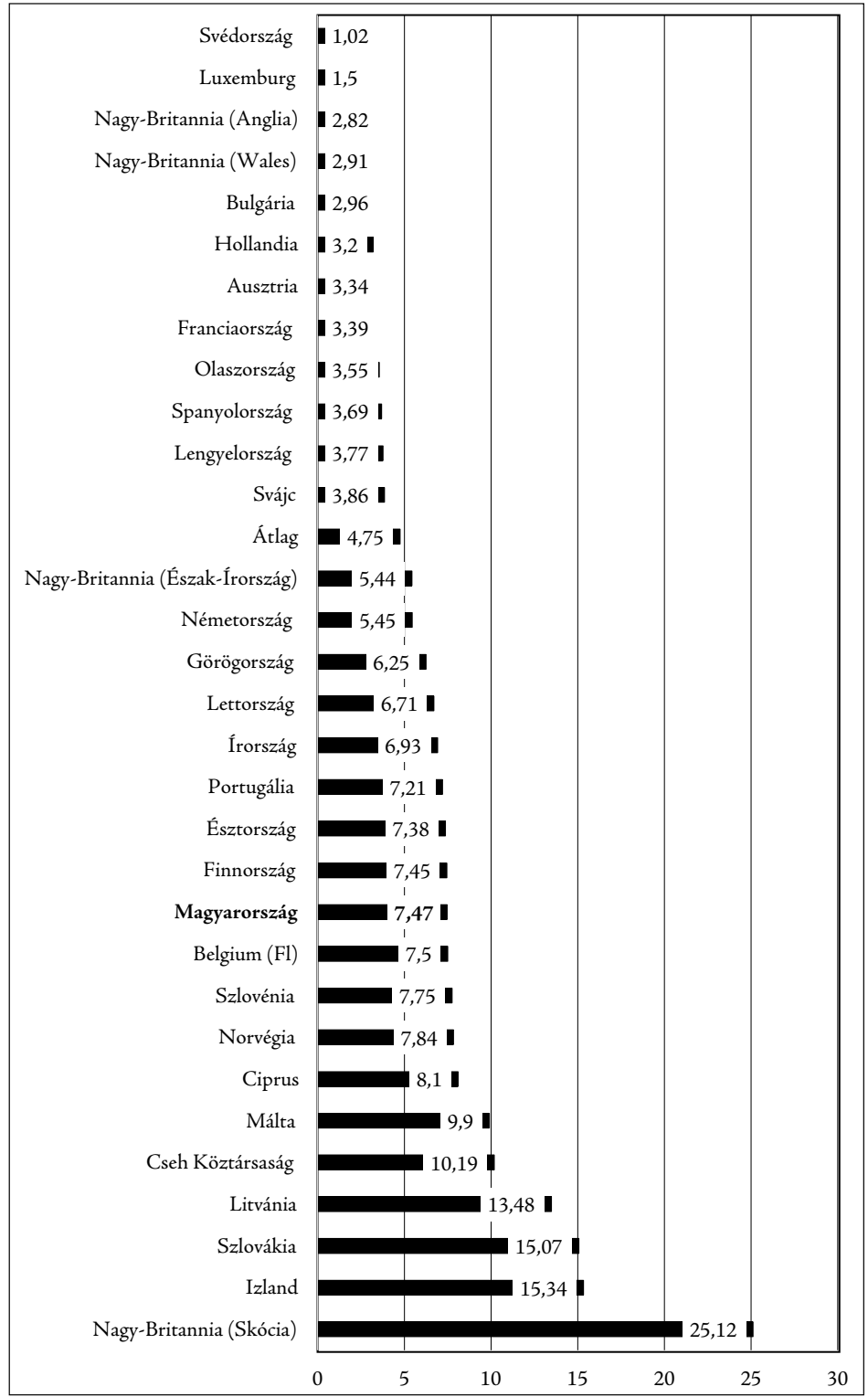

1. ábra: Az SNI tanulók aránya a beiratkozott tanulókhoz viszonyítva (\%)

Forrás: EASIE 2018 Data-set Cross-Country Report 
volt. Az adatok igen nagy a szórást mutatnak, 1\% (Svédország) és 25\% (Skócia, UK) között mozognak. ${ }^{2}$ Nem valószínü, hogy az adatok mögött kizárólag biológiai okok húzódnak meg, sokkal inkább a kategóriába tartozók meghatározásának különbségeiről van szó.

A nemzetközi szinten hivatalosan SNI-ként elismert tanulók körébe tartoznak $A$ fogyatékos emberek jogairól szóló egyezmény (Egyesült Nemzetek Szervezete 2006) szerint meghatározott fogyatékossággal élő tanulók, ${ }^{3}$ de az eltérések egyik oka, hogy idesorolódnak olyan tanulói csoportok is, melyek az adott társadalmi környezetben tanulmányaik végzéséhez plusztámogatást és ehhez erőforrásokat igényelnek. Az Agency megállapítása (2018) szerint ezen csoportok heterogenitása és a számosságban megjelenő különbségek a fó okai az országok közti adatok eltéréseinek. A sajátos nevelési igény kategóriába tartozhatnak a fogyatékosságok (értelmi fogyatékosság, hallássérülés, látássérülés, testi fogyatékosság, nyelv-beszéd rendellenessége, autizmus spektrum zavar, halmozott fogyatékosság) csoportjain kívül a speciális (krónikus) egészségügyi helyzetü tanulók mellett azok is, akik kulturális és/vagy nyelvi nehézséggel küzdenek: nem beszélik az adott ország nyelvét (bevándorlók, menekültek), vagy nem anyanyelvük az adott nyelv; valamint a különféle gazdasági-társadalmi hátrányok is helyet kapnak: nem rendelkeznek megfelelő tanulási környezettel, családi körülményeik miatt veszélyeztetettek, szociális körülményeik nem megfelelőek. Ezen csoportok mellett nemritkán a kiemelkedő tehetségeket is ide sorolják be, bár a jogi szabályozás e tekintetben is országonként igen eltérő. A hazai jogalkotásban a köznevelési törvény az Értelmező rendelkezések (4. paragrafus) 13. pontjában a kiemelt figyelmet igénylő gyermek, tanuló kategóriája alá sorolja a különleges bánásmódot igénylő gyermekeket, tanulókat, ahova három tanulói csoport tartozik: a sajátos nevelési igényü gyermekek, tanulók; ${ }^{4}$ a beilleszkedési, tanulási, magatartási nehézségekkel küzdő gyermekek, tanulók, ${ }^{5}$ valamint a kiemelten tehetséges gyermekek, tanulók. ${ }^{6}$ A kiemelt figyelmet igénylő gyermekek körébe tartoz-

Számítási mód: (SNI státuszt jelző dokumentummal rendelkező tanulók száma / formális képzésre beiratkozott tanulók száma) × 100 .

3 Az ENSZ-egyezmény 1. cikke a Cél megjelölésénél a következő meghatározást használja: „Fogyatékossággal élő személy minden olyan személy, aki hosszan tartó fizikai, értelmi, szellemi vagy érzékszervi károsodással él, amely számos egyéb akadállyal együtt korlátozhatja az adott személy teljes, hatékony és másokkal egyenlő társadalmi szerepvállalását."

4 Köznevelési törvény, 4. paragrafus, 25. pontja: sajátos nevelési igényü gyermek, tanuló: az a különleges bánásmódot igénylő gyermek, tanuló, aki a szakértői bizottság szakértői véleménye alapján mozgásszervi, érzékszervi (látási, hallási), értelmi vagy beszédfogyatékos, több fogyatékosság együttes elöfordulása esetén halmozottan fogyatékos, autizmus spektrum zavarral vagy egyéb pszichés fejlődési zavarral (súlyos tanulási, figyelem-vagy magatartásszabályozási zavarral) küzd...

5 Köznevelési törvény, 4. paragrafus 3. pontja: beilleszkedési, tanulási, magatartási nehézséggel küzdő gyermek, tanuló: az a különleges bánásmódot igénylő gyermek, tanuló, aki a szakértői bizottság szakértői véleménye alapján az életkorához viszonyítottan jelentősen alulteljesít, társas kapcsolati problémákkal, tanulási, magatartásszabályozási hiányosságokkal küzd, közösségbe való beilleszkedése, továbbá személyiségfejlődése nehezített vagy sajátos tendenciákat mutat, de nem minősül sajátos nevelési igényűnek...

6 Köznevelési törvény, 4. paragrafus, 14. pontja: kiemelten tehetséges gyermek, tanuló: az a különleges bánásmódot igénylő gyermek, tanuló, aki átlag feletti általános vagy speciális képességek birtokában magas fokú kreativitással rendelkezik, és felkelthető benne a feladat iránti erős motiváció, elkötelezettség... 
nak még a hátrányos és halmozottan hátrányos helyzetű gyermekek, tanulók, ${ }^{7}$ körüket pedig a gyermekek védelméről és a gyámügyi igazgatásról szóló törvény határozza meg.

Emellett a felismerési arány is nagymértékben különbözik az egyes országokban, melyek hátterében jogszabályi és szakpolitikai eltérések húzódnak meg, és a diagnosztizálás útjai is eltérőek lehetnek. Míg Magyarországon a pedagógiai többletszolgáltatások (pl. egészségügyi és pedagógiai célú habilitációs és rehabilitációs foglalkozás), valamint az egyéb többletjogok (pl. kedvezmények, mentesítések) feltétele, hogy a gyermek, tanuló rendelkezzen szakértői bizottság által kiadott szakértői véleménnyel, ${ }^{8}$ addig más országokban, pl. Angliában a többlettámogatások nem feltétlenül kötődnek szakértői vizsgálatokhoz. Az iskolák - tantervük részeként - nyújtanak segítséget mindazon tanulók számára, akiknek erre szükségük van. A támogatás az osztályfönök és az SNI-koodinátor (SENDCO - Special Educational and Disability Coordinator) szervezésében zajlik, és külső szakemberek, szaktanácsadók igénybevételére is lehetőség van. A magyar szakértői véleménynek nagy vonalakban megfeleltethető EHCP (Educational and Health Care Plan - Oktatási és Egészségügyi Gondozási Terv) kiállítása egy hosszabb folyamat, melynek előkészítésében jelentős szerepe van az SNIkoordinátornak. A tervet a helyi oktatási hatóságok állítják ki a begyüjtött információk és a felmérés alapján.

1997. évi XXXI, törvény (gyermekvédelmi törvény) 67/a paragrafusa értelmében a hátrányos, halmozottan hátrányos helyzet szempontjából meghatározó tényezők a következők: a szülő, a családba fogadó gyám (a továbbiakban: gyám) iskolai végzettsége alacsony; legfeljebb alapfokú végzettség (8 általános); a szülő, gyám alacsony foglalkoztatottsága; az elégtelen lakáskörülmények; a nevelésbe vétel, valamint a tanulói, hallgatói jogviszonyban álló fiatal felnőtt számára nyújtott utógondozói ellátás. Hátrányos helyzetű gyermek: az a rendszeres gyermekvédelmi kedvezményre jogosult gyermek, aki esetében az alábbi körülmények közül egy fennáll: a rendszeres gyermekvédelmi kedvezmény igénylésének időpontjában a gyermeket együtt nevelő mindkét szülő, a gyermeket egyedül nevelő szülő, illetve a gyám legmagasabb iskolai végzettsége alapfokú (az alacsony iskolai végzettség igazolása a kérelmen megtett önkéntes nyilatkozattal történik); a rendszeres gyermekvédelmi kedvezmény igénylésének időpontjában a gyermeket nevelő szülők bármelyike vagy a gyám a szociális törvény szerinti aktív korúak ellátására jogosult (foglalkoztatást helyettesítő támogatás vagy rendszeres szociális segély), vagy a kedvezmény igénylését megelöző 16 hónapon belül legalább 12 hónapig álláskeresőként tartotta nyilván a járási munkaügyi kirendeltség (az alacsony foglalkoztatottság fennállását az eljáró hatóság ellenőrzi); a gyermek szegregátumnak nyilvánított lakókörnyezetben, vagy az eljárás során felvett környezettanulmány szerint félkomfortos, komfort nélküli vagy szükséglakásban, illetve olyan lakáskörülmények között él, ahol korlátozottan biztosítottak az egészséges fejlődéshez szükséges feltételek (elégtelen lakókörnyezet, illetve lakáskörülmény). Halmozottan hátrányos helyzetű gyermek: az a rendszeres gyermekvédelmi kedvezményre jogosult gyermek, aki esetében a fenti három körülmény közül (alacsony iskolai végzettség, alacsony foglalkoztatottság, elégtelen lakókörnyezet, illetve lakáskörülmény) legalább kettő fennáll. Halmozottan hátrányos helyzetủ továbbá a nevelésbe vett gyermek és az utógondozói ellátásban részesülő, tanulói vagy hallgatói jogviszonyban álló fiatal felnőtt.

8 Magyarországon az SNI-diagnosztika többlépcsős folyamat. Elsőként a járási szinten működő szakértői bizottsághoz kell fordulnia a szülőnek és/vagy a nevelési-oktatási intézménynek, ha felmerül az atipikus fejlődés gyanúja. A járási szakértői bizottság azonban kizárólag beilleszkedési, tanulási, magatartási nehézséget állapíthat meg. Ha a vizsgálat ennél súlyosabb problémát jelez (SNI-gyanú), a gyermeket tovább irányítják a megyei szakértői bizottsághoz, amely jogosult a sajátos nevelési igény megállapítására, a többlettámogatásokat tartalmazó szakértői vélemény kiadására. A vizsgálat komplex, orvosi, pszichológiai, pedagógiai és gyógypedagógiai részekből tevődik össze. Ennek alapján tesznek javaslatot a különleges gondozás keretében történő ellátásra, annak formájára, helyére, vagyis speciális osztályokba helyezésre vagy integráló, többségi iskola osztályába való elhelyezésre. 


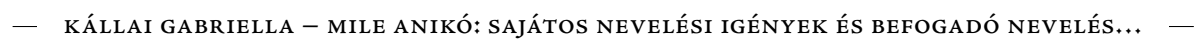

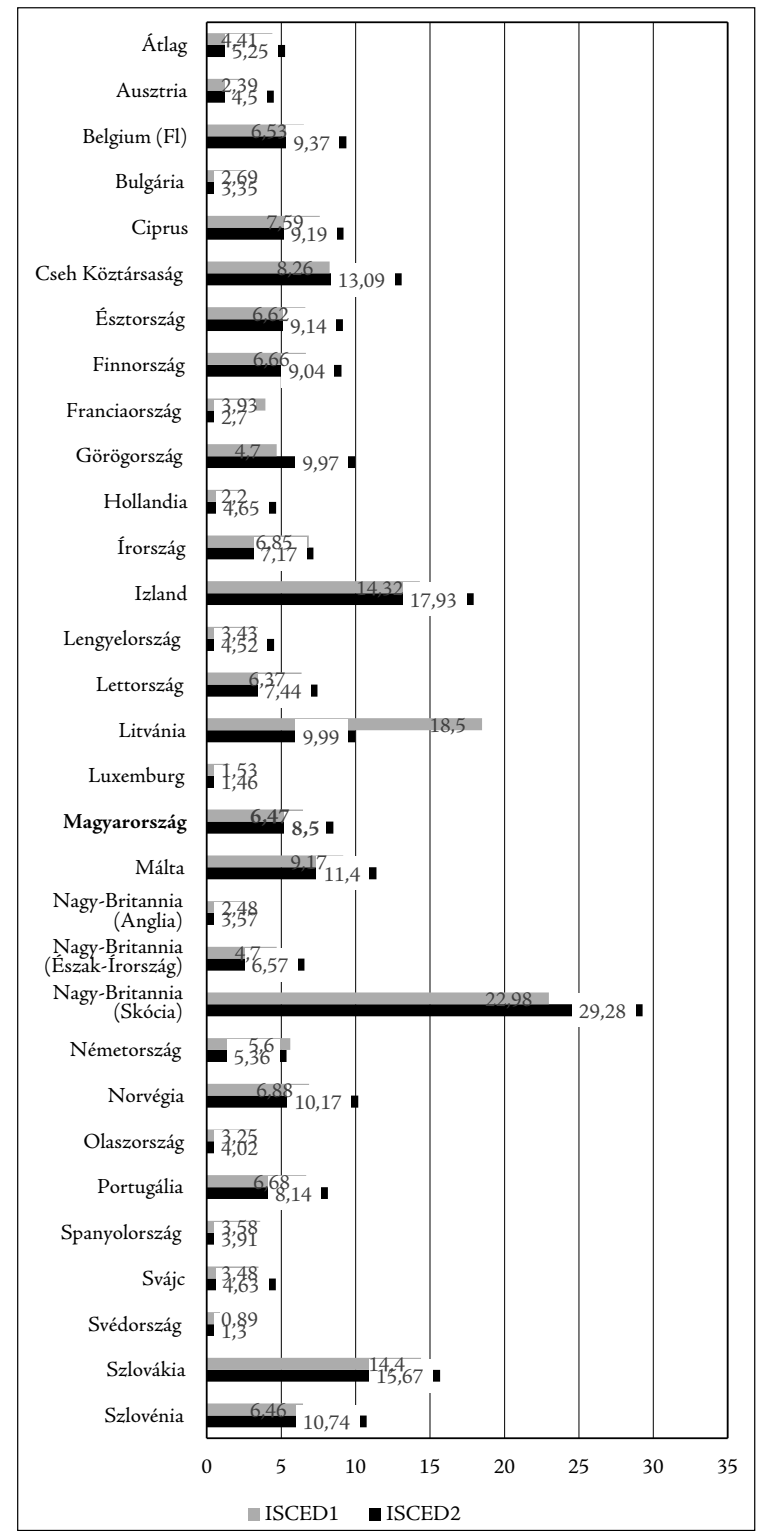

2. ábra: SNI tanulók az alapfokú oktatásban (ISCED1 és ISCED2) Forrás: EASIE 2018 Data-set Cross-Country Report

Az SNI tanulók felderítésére vonatkozó mutató, hogy az alapfokú oktatási rendszerekben (9 éves korban vizsgálva) ISCED1 ${ }^{9}$ szinten 4,4\%-ban találunk SNI tanulókat, arányuk ISCED2 szinten (15 éves korban) a legtöbb országban magasabb, 5,6\% (2.ábra).

9 ISCED1: a hazai általános iskola 1-4, osztálya, ISCED2: a hazai általános iskola 5-8, osztálya. 
$\mathrm{A} z$ adatok azt mutatják, hogy az egyes országok sok esetben a diákok iskolai tanulmányainak eltérő szakaszában ismerik fel a problémákat, és igényelnek a megoldáshoz speciális támogatást. Az inkluzív megközelítés a szürésnél más eljárásrendet igényel: a kategorizáció vagy teszteken alapuló diagnosztika helyett a gyermeket/tanulót saját tanulói környezetében (óvoda, iskola) vizsgálva figyelik meg motivációit, sikereit, kudarcait stb., és erre építik fel az egyéni fejlesztési tervet. A nemzetközi gyakorlatban a státuszdiagnosztikát (mely egyszeri mérésen alapul) egyre inkább a folyamatdiagnosztika, fejlesztésdiagnosztika és szükségletorientált diagnosztika váltotta fel, életkorhoz illeszkedő vizsgálatokkal, terápiás eljárásokkal (Lányiné Engelmayer 2014). Ezek gyakorlati megvalósulását mutatja a következő néhány példa. A szolgáltatott adatok szerint kiemelkedően magas számú SNI tanulókat ellátó Skóciában, ahol a tanulók negyede kap valamilyen többlettámogatást, ez a következőképpen zajlik: első lépésben a tanár azonosítja a gyermekeket, akiknek nagyobb figyelemre van szükségük; ezt követően a pedagógus az iskolán belül konzultál, és támogatást kap a menedzsmenttől, valamint a személyzet más tagjaitól. Ha ezen az úton nem sikerül megoldani a problémát, az iskola szülőket is bevonva információkat és tanácsokat kér a helyi oktatási hatóságok által mủködtetett szolgálattól (látogató tanár vagy pszichológus ad tanácsokat). Ha ez nem elegendő, szükség lehet más, az oktatáson kívüli szervezet(ek) támogatására is. A szülőknek joguk van arra, hogy kérjék a gyermekük vizsgálatát (akár több specifikus területen is: orvosi, pedagógiai vagy pszichológiai értékelés), és összehangolt támogatási terv kidolgozását. Az általános cél az, hogy meghatározzák azokat a támogatási formákat, melyek a tanulót az oktatásban való teljes részvételhez segítik hozzá (pl. tanulást támogató tanár vagy asszisztens közremüködésével, de más segítőkre is szükség lehet akár a fizikai gondozás, akár más szakmák bevonásával: pszichológus, orvos, ápoló, gyógytornász, szociális munkás, különféle terapeuták). A tanulók fejlődését egyéni fejlesztési tervvel biztosítják, a pedagógusoktól pedig elvárják, hogy ismerjék és vegyék figyelembe a tervben rögzítetteket.

Finnországban, ahol az SNI tanulók aránya a hazaihoz hasonló, a PISA-mérések sikerei miatt valószínüsíthető, hogy nagy hangsúlyt fektetnek a hátrányos helyzetből induló tanulók támogatására. Sok más országhoz hasonlóan kifejezetten törekszenek arra, hogy a lehető legkorábban támogatást biztosítsanak a problémák növekedésének megelőzése érdekében. A jogszabályok nem osztályozzák a tanulókat fogyatékosság vagy támogatási igények szerint. Elöször az iskola mindennapi életének részeként általános támogatást kap a tanuló, akár átmeneti, akár folyamatos támogatási szükséglet merül fel. Ha ez nem elegendő, pedagógiai értékelés alapján intenzívebb támogatási terv készül szélesebb körű iskolai team bevonásával. Ha további intézkedésekre van szükség, átfogóbb vizsgálatok készülnek, és napvilágot lát a speciális támogatásról szóló döntés, leggyakrabban a tanuló 2-7. osztályos kora közt.

A nemek közti különbségekre vonatkozóan szembetűnő, hogy az SNI tanulók között átlagosan kétszer annyi fiút találunk, mint lányt (3. ábra). Ez az arány igen hasonló valamennyi adatot szolgáltató országban. Elhelyezésük a különböző tanítási környezetekben, vagyis hogy speciális intézményekben vagy a többségi iskolákban, integrált vagy inkluzív módon nevelik őket, nem mutat eltérést. Arra vonatkozóan még nincsenek pontos ismereteink, hogy a nemek közti különbségeket milyen okok magyarázhatják. Lehetséges, hogy biológiai vagy viselkedési tényezők állnak a háttérben, emellett elképzelhető az is, hogy a fuúk oktatására-nevelésére hagyományosan nagyobb figye- 


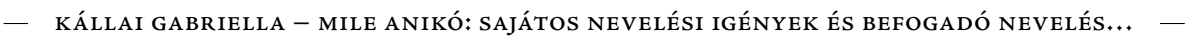

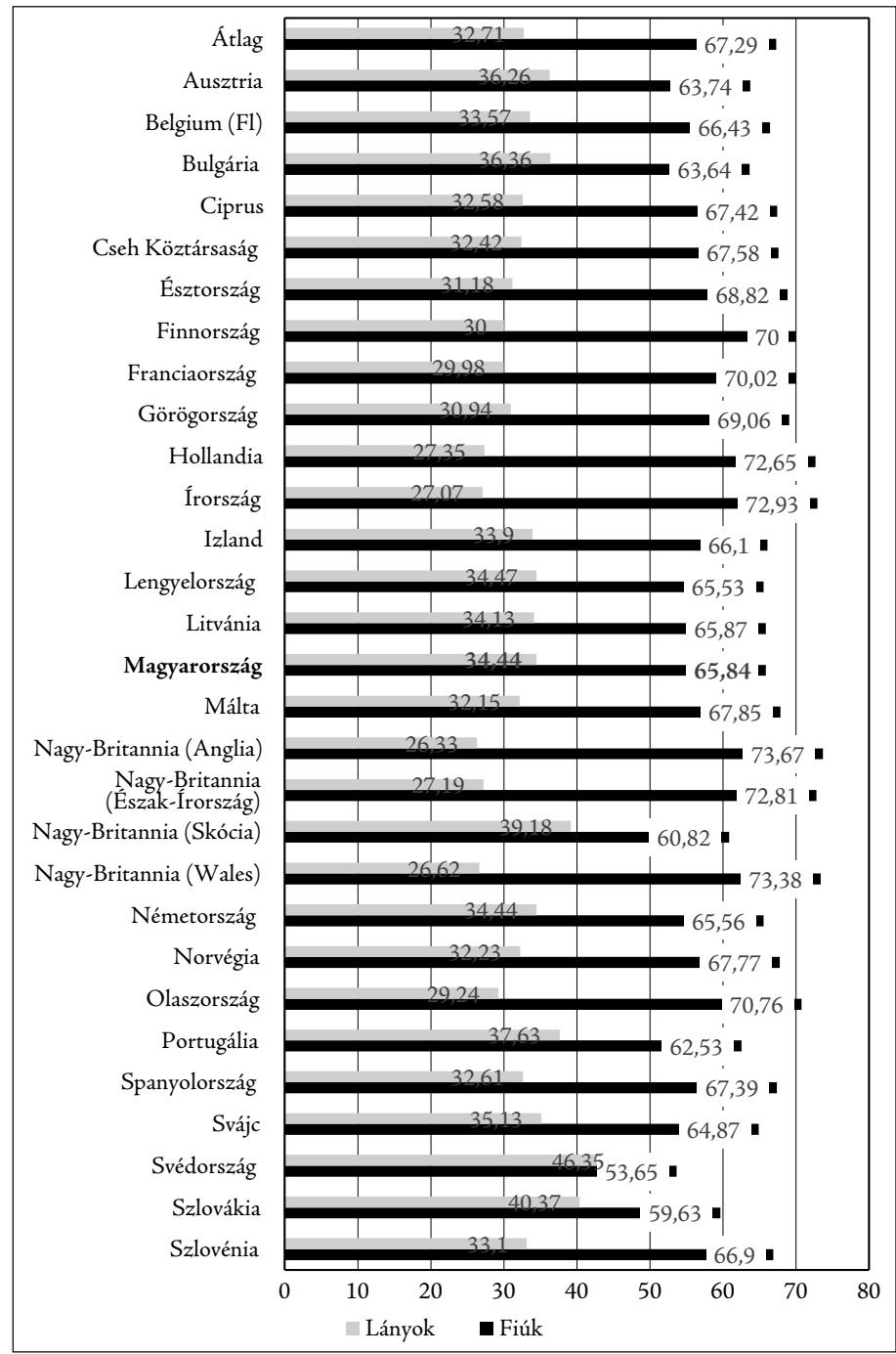

3. ábra: Nemek közti különbségek az SNI tanulóknál (\%) ${ }^{10}$ Forrás: EASIE 2018 Data-set Cross-Country Report

lem fókuszálódik, mint a lányokéra (Csányi 2007). Autizmus spektrum zavar esetében kutatások igazolják, hogy a lányoknál gyakoribb a félrediagnosztizálás vagy a későbbi diagnózis, ennek oka lehet az eltérő tüneti kép vagy a diagnosztizáláshoz használt eszköztár, melyet elsősorban fiúkra alakítottak ki (Egészségügyi szakmai irányelv 2017).

A speciális nevelési igényü gyermekek oktatása-nevelése többféleképpen valósulhat meg: a befogadó intézményekben a többiekkel együtt, vagy ugyanitt elkülönített, speciális osztályokban tanulhatnak, vagy speciális intézményekben, továbbá nem formális keretek között. A vizsgált országok egyikében sem müködik a teljes mértékben befoga-

10 Itt a számítási mód: (SNI fiúk / összes fiú tanuló) × 100; (SNI lány / összes lány tanuló) × 100 . 


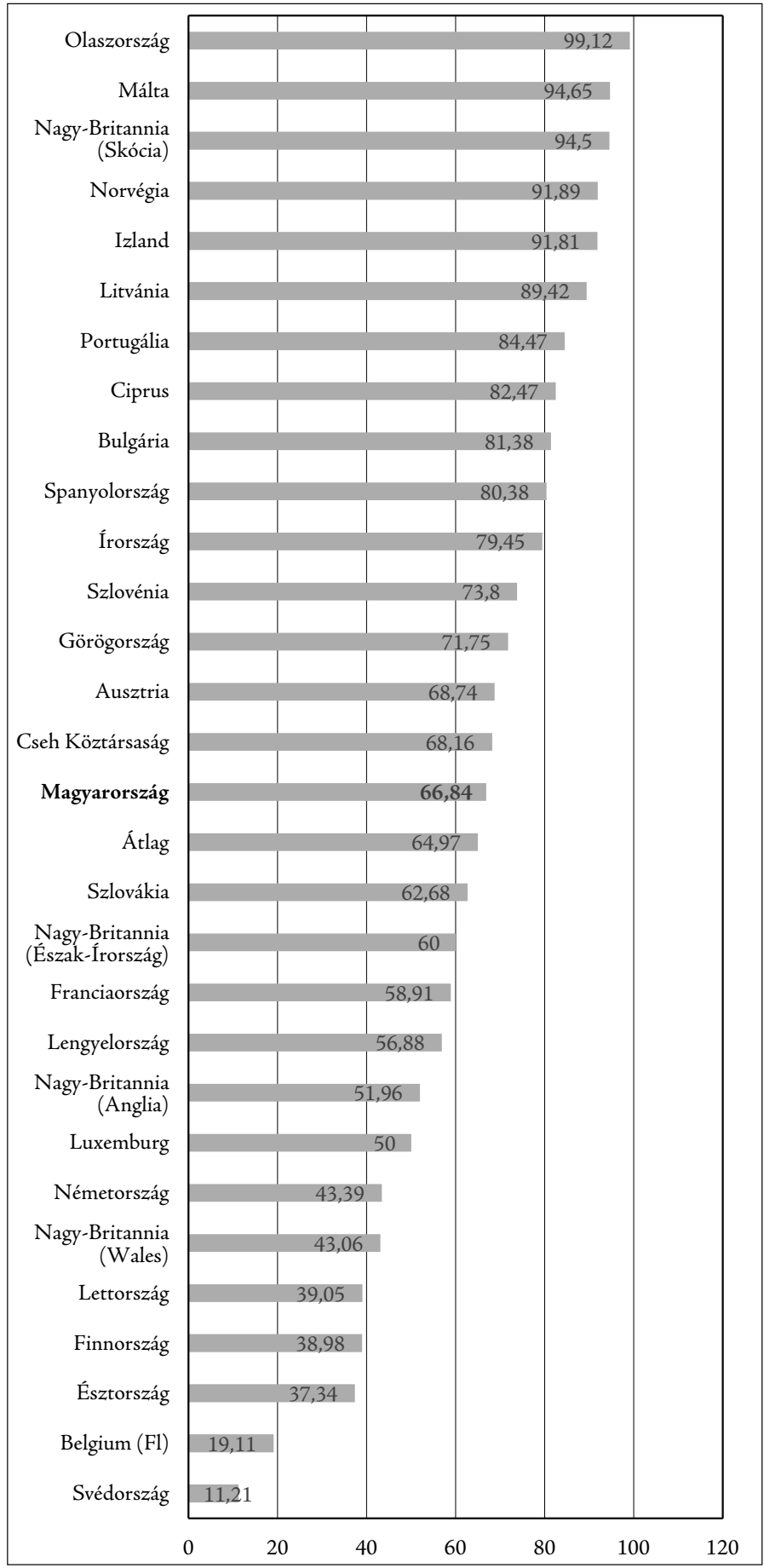

4. ábra: $\mathrm{A} z$ együttnevelésben részt vevő SNI tanulók aránya (\%) Forrás: EASIE 2018 Data-set Cross-Country Report 
dó rendszer, vagyis az, hogy minden tanuló a többségi oktatásban vesz részt, és a tanítási idő legalább 80\%-ában együtt tanul a többi diákkal (4.ábra). Legtöbb országban ma már törekednek arra, hogy minél szélesebb körben biztosítsák a befogadó nevelést az érintett tanulók számára, és csak a súlyos vagy halmozott esetekben tanácsolják a speciális intézményekben való tanulást. Fontos megjegyezni, hogy lényegesen többen tanulnak befogadó intézményben, intézményegységben úgy, hogy idejük csak kisebb hányadát töltik együtt a többiekkel (szünetek stb.). Sok országban hasonló helyzetben vannak az adott ország nyelvét nem beszélő tanulók: számukra gyakran szerveznek külön osztályokat nyelvtanító jelleggel (eltérő időtartammal), hogy lehetőség szerint onnan később a többségi oktatási rendszerben, kortársaikkal együtt tanulhassanak.

Az ezredforduló táján készült tematikus elemzés (Speciális oktatás Európában 2003) három csoportba sorolta az országokat a speciális oktatást igénylő tanulók bevonására irányuló szakpolitikák alapján. Ezek a tradicionális különbségek máig hatnak, annak ellenére, hogy egyre több ország gyakorlata mozdul el az együttnevelés irányába. Az ún. egyutas (one-track) megközelítésben elsősorban a diákok mainstream oktatásba való bevonása volt jellemző (Spanyolország, Görögország, Olaszország, Portugália, Svédország, Izland, Norvégia, Ciprus), ezekben az országokban az intézményesített, külön oktatási forma gyakorlatilag megszünt. Másik végletként a kétutas (two-track) megközelítésben két elkülönült oktatási rendszer jelent megः jogszabályi szinten is gyakran külön szabályok vonatkoztak a speciális oktatásban részesülő diákokra (Belgium, Svájc). A többutas (multi-track) modellek esetében pedig az inklúzió többfajta megjelenési formája valósul meg, külön fejlesztési lehetőségeket biztosítva az érintett tanulóknak (Dánia, Franciaország, Írország, Luxemburg, Ausztria, Finnország stb.) A legtöbb országban megfigyelhető az együttnevelés kiszélesítése, és ezzel egyidejűleg tendenciaként jelenik meg a speciális iskolák szolgáltatási forrásközponttá válása (Vargáné 2004). Két, az együttnevelés szempontjából kiemelkedő ország példájával illusztráljuk, miként valósul meg az iskolai nevelés támogatása.

Olaszországban 1977-ben törvényben rögzítették a speciális iskolák bezárását, és a befogadás elve széles körben elfogadott, egyénre szabott fejlesztési terv alapján zajlik az SNI tanulók oktatása-nevelése. Ebben multidiszciplináris team vesz részt, az iskolában dolgozó pedagógusok és más szakemberek bevonásával. Minden iskolában működik ún. befogadási munkacsoport, melynek tagjai pedagógusok, segítő tanárok, adminisztratív dolgozók, valamint egészségügyi szakemberek. Az iskolai munka során gyakran alkalmaznak ún. támogató tanárokat, akik speciális képzésben részesültek. Ök kéttanáros modellben dolgoznak együtt a többségi pedagógusokkal. Nem ritka az sem, hogy a tanulók részére speciális képzettségű asszisztenseket is biztosítanak, hogy segítsék a diák önállóságát és kommunikációját (National Education Systems - Eurydice).

Dániában az egyes iskolák felelőssége a tanulói igényekhez és szükségletekhez illeszkedő tanítási módszerek, oktatási anyagok összeállítása. Ehhez átfogó keretet biztosít a differenciált oktatás, a pedagógusok pedig jelentős autonómiát élveznek, akár a tanítási módszerekről, akár a tananyag összeállításáról beszélünk. Amennyiben a differenciálás nem elegendő, más eszközöket (csoportképzés, kéttanáros modellek, pedagógiai aszszisztensek alkalmazása) is alkalmaznak a dán iskolákban. Érdemes megjegyezni, hogy itt, ha a tanulónak heti 9 óránál kevesebb oktatási támogatásra van szüksége, akkor a hagyományos/többségi osztályban kell megoldani a tanítását, ha ennél többre, akkor egyéni mérlegelés alapján, pedagógiai, pszichológiai szakértőkkel és szülőkkel folytatott 
konzultáció alapján születik meg a döntés arról, hogy speciális oktatásban szükséges-e részesíteni a tanulót (National Education Systems - Eurydice).

\section{Magyar helyzet}

Hazánkban, bár a rendszerváltás után is tovább élt a gyógypedagógia tradicionális szegregált gyakorlata (Illyés 2001), ha az elmúlt 20-30 évet tekintjük, szembetűnő, hogy az SNI tanulók számának és arányának kismértékű ingadozása mellett (melyet egy országos felülvizsgálat indokol) a nemzetközihez hasonló tendencia alakult ki az együttnevelés terén, jelentősen nőtt az integráltan oktatott tanulók száma: a 2001-ben még 18\%-ról 2016-ban már 70\%-ra emelkedett (1. táblázat, 5. ábra).

1. táblázat: Az integráltan tanuló SNI tanulók száma és aránya (2001-2016)

\begin{tabular}{lccccc}
\hline Tanév & $\begin{array}{c}\text { Összes tanuló } \\
\text { (általános } \\
\text { iskola, nappali) }\end{array}$ & $\begin{array}{c}\text { SNI tanulók } \\
\text { száma } \\
(\text { fó) }\end{array}$ & $\begin{array}{c}\text { SNI tanulók } \\
\text { aránya } \\
(\%)\end{array}$ & $\begin{array}{c}\text { Integráltan tanu- } \\
\text { ló SNI tanulók } \\
\text { száma (fó) }\end{array}$ & $\begin{array}{c}\text { Integráltan tanu- } \\
\text { ló } \\
\text { aránya (\%) }\end{array}$ \\
\hline $2001 / 2002$ & 944244 & 46575 & 4,9 & 8263 & 18 \\
$2002 / 2003$ & 930386 & 49967 & 5,3 & 12941 & 26 \\
$2003 / 2004$ & 909769 & 54055 & 5,9 & 18584 & 34 \\
$2004 / 2005$ & 887785 & 56922 & 6,4 & 24067 & 42 \\
$2005 / 2006$ & 859315 & 60651 & 7,0 & 29930 & 49 \\
$2006 / 2007$ & 828943 & 61585 & 7,4 & 33277 & 54 \\
$2007 / 2008$ & 809160 & 57931 & 7,6 & 32719 & 56 \\
$2008 / 2009$ & 788639 & 52945 & 6,7 & 30128 & 57 \\
$2009 / 2010$ & 773706 & 52572 & 6,8 & 31762 & 60 \\
$2010 / 2011$ & 756569 & 52165 & 6,9 & 32573 & 62 \\
$2011 / 2012$ & 747601 & 51899 & 6,9 & 33298 & 64 \\
$2012 / 2013$ & 742931 & 51654 & 6,9 & 33791 & 65 \\
$2013 / 2014$ & 747746 & 51681 & 6,9 & 34599 & 67 \\
$2014 / 2015$ & 748486 & 52502 & 7,0 & 35591 & 68 \\
$2015 / 2016$ & 745323 & 53577 & 7,2 & 36858 & 69 \\
$2016 / 2017$ & 741427 & 54678 & 7,4 & 38210 & 70 \\
\hline
\end{tabular}

Forrás: $\mathrm{KSH}$

Ennek oka többek közt a törvényi szabályozók megteremtése, mely egyfelől a fogyatékos személyek jogairól és esélyegyenlőségük biztosításáról rendelkezik, másfelől a közoktatásról, majd a köznevelésről szóló törvény adott kereteket. Arról sem szabad megfeledkeznünk, hogy bár Magyarországon az elkülönült gyógypedagógiai nevelésnek-oktatásnak komoly hagyományai vannak, mégis a kitüzött cél és feladat a fogyatékos gyermekek, tanulók társadalmi vagy munkaerö-piaci integrációjának majdani megteremtése, azaz a sérült emberek társadalomba való (vissza)segítése. E hagyomány- 


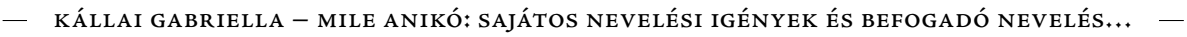

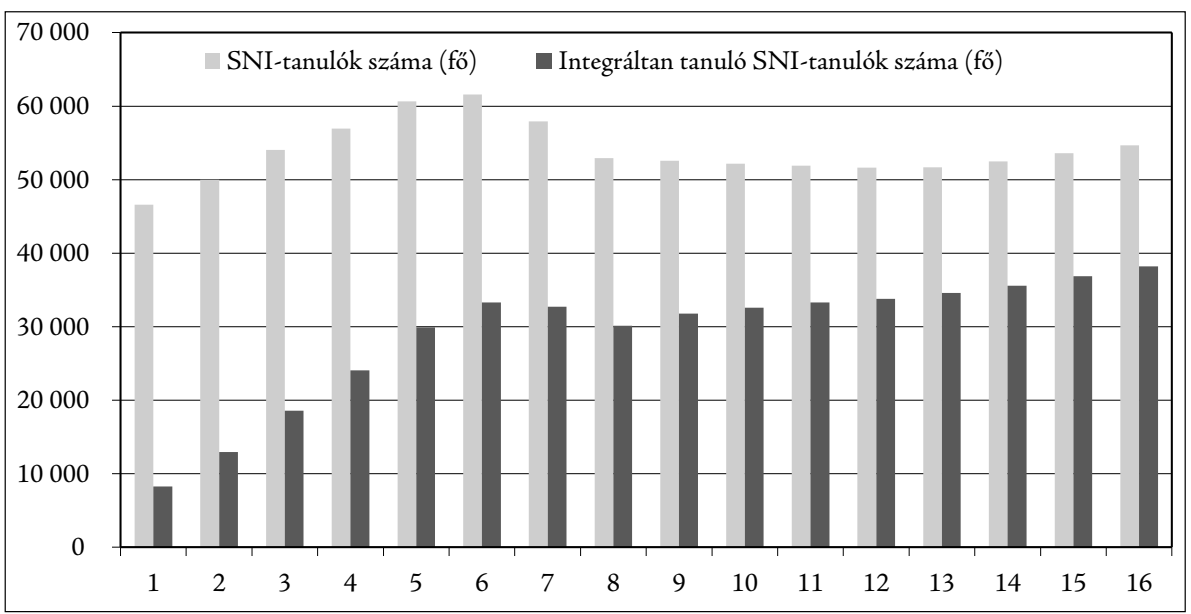

5. ábra: SNI tanulók és integráltan tanuló SNI diákok száma a hazai általános iskolákban (2001-2016) (Forrás: KSH)

ból is következik, hogy az oktatási rendszeren belül létrejövő együttnevelés szemlélete hazánkban egyáltalán nem magától értetődően a pedagógiai kultúra része. A kezdeti várakozásokat és félelmeket az oktatáspolitika kiemelt fejlesztési és pályázati programokkal igyekezett befolyásolni, országos szintủ integrációs programok indultak. Az EU-csatlakozás után pedig a hazai fejlesztési programok uniós forrásokból valósulnak meg (Köpatakiné 2009). Az együttnevelés hazai bevezetése - bár az oktatáspolitikai akarat egyértelmű volt, és a jogi keretek is kialakításra kerültek - iskolaszervezési, pedagógusképzési és szakmódszertani problémákkal járt együtt. Ez egyrészről érintette a hagyományos gyógypedagógiai intézmények munkáját: csökkent a tanulói létszám, és ezzel egyidejűleg az intézmények egy része integrációt, inklúziót segítő módszertani intézménnyé alakult át. Másfelől a sajátos nevelési igényű tanulók megjelenése, fogadása a többségi köznevelési intézményekben nem zökkenőmentes folyamat, rávilágít a pedagógiai környezet hiányosságaira (Mile 2016).

A hatályos jogszabályok értelmében a sajátos nevelési igényű tanuló csak olyan intézménybe íratható be, amely rendelkezik az oktatásához-neveléséhez szükséges tárgyi és személyi feltételekkel. Az ellátáshoz szükséges objektív és szubjektív feltételek közül az objektívek (az akadálymentes környezet kialakítása, a speciális, sérülésspecifikus, tapasztalatszerzést segítő taneszközök, szemléltető eszközök, tankönyvek, munkafüzetek és fejlesztőeszközök beszerzésének lehetősége, korszerű tankönyvek, tanársegédanyagok megléte stb.) viszonylag könnyen vizsgálhatók, és elméletileg a szándékok mentén viszonylag könnyen megteremthetők. Ugyanakkor kutatások sora bizonyítja, hogy ezek hiányosan teljesülnek, az intézmények szintjén nehézséget okoz a szakemberhiány, az infrastrukturális és tárgyi feltételek biztosítása. A szubjektív, azaz emberi tényezők lényegesen nehezebben ragadhatók meg. Ez az összegzés nem is vállalkozik arra, hogy valamennyi szereplő együttneveléssel kapcsolatos feladatait, tevékenységét és attitűdjét feltárja. Így, bár tudjuk, hogy az együttnevelés szemlélete maga után vonja a pedagógus- és gyógypedagógus-szerep átformálódását is, a kapcsolódó feladatok és azok megvalósítása többletmunkát és szakértelmet, együttműködést követelnek meg mind a tantestületek, mind az egyes pedagógusok részéről (Kállai 2018). Különösen 
fontos szerepük van az intézményi szintű megvalósításoknak, melyek nemritkán maguk után vonják az innovációkat (Papp-Perlusz 2012), ennek részeként a tantestületek képzésének, továbbképzésének, szemléletformálásának. Érdemes figyelmet fordítani a gyógypedagógusok felkészítésére is, hogy a befogadó intézményekben el tudják látni feladataikat (Szekeres-Perlusz-Takács 2012; Schiffer 2012).

\section{Összegzés}

$\mathrm{A} z$ inkluzív nevelésre és sajátos nevelési igényre vonatkozó szakpolitikák és gyakorlatok az Európai Unió államaiban sokat fejlődtek, ugyanakkor nem választhatók el az egyes országokra jellemző sajátos kontextusoktól, ezért ma is nagyon különbözőek. Összességében igen fontos vonás, hogy az elmúlt évtizedekben szemléletváltás következett be: az intraperszonális tényezőkről egyre inkább a speciális vagy kiegészítő ellátásra kerül a hangsúly több országban, és ezzel párhuzamosan tapasztalható elmozdulás az ún. orvosi/medikális modellen ${ }^{11}$ alapuló meghatározásoktól és ellátásoktól az „interakcionalista” meghatározások felé. Az uniós szakpolitikákban és célkitűzések között jelentős szerepet kap többek közt a fogyatékos vagy más okok miatt perifériára kerülő emberek maradéktalan társadalmi befogadása és hozzájárulásuk segítése a társadalom alakításához. E célok mentén a sajátos nevelési igény nemzetközi értelmezése kitágult (viszont nem egységesedett), és ennek következtében valósul meg egyre nagyobb mértékben az oktatás területén az együttnevelés. A megvalósítás módjai igen eltérőek lehetnek, akár országonként, akár az egyes országokon belül, intézményi szinten vizsgálódunk. Az integráción túlmutató inklúziós modellben a problémák elsődleges megoldása az osztályteremben tanító pedagógus kezében van, ugyanakkor speciálisan képzett szakemberek bevonása is szükséges. Az inkluzív iskola egyénre szabott tanítási stratégiákat javasol, amelyek túlmutatnak a hagyományos osztály keretein, annak érdekében, hogy megfeleljenek minden gyermek igényének. Ennek gyakorlati megvalósításához elengedhetetlen a szükséges feltételrendszer kialakítása, melynek része az iskolák falain belüli feltételek biztosítása mellett többek közt az elfogadó társadalmi környezet megteremtése is.

\section{IRODALOM}

Csányi Y. (2007) Adatok az OECD sajátos nevelési igényű tanulókkal foglalkozó munkabizottságának anyagából, 2002/2003-as év. Új Pedagógiai Szemle, 2007/11. https:// folyoiratok.oh.gov.hu/uj-pedagogiai-szemle/adatok-az-oecd-sajatos-nevelesi-igenyutanulokkal-foglalkozo-munkabizottsaganak/ [Letöltve: 2020. 08. 26.]

Egészségügyi szakmai irányelv (2017) Egészségügyi szakmai irányelv - Az autizmusról/ Autizmus spekrumzavarokról. Emberi Erőforrások Minisztériuma, Egészségügyért Felelős Államtitkárság. https://kollegium.aeek.hu/Iranyelvek/Index/ [Letöltve: 2020. 08. 26.]

Egyesült Nemzetek Szervezete (2006) A fogyatékossággal élő személyek jogairól szóló egyezmény. - Magyarul is törvénybe iktatták: https://net.jogtar.hu/jogszabaly?docid= a0700092.tv

11 Orvostudományi szempontból történik a fogyatékosságok azonosítása, kategorizálása, a diagnózis a deficitek megállapítására vonatkozik, az erre épülő pedagógia a károsodásra összpontosít, az elkülönített kezelést preferálja. 
— KÁllai gabriella - Mile ANIKó: SAJÁTOS NEVElÉSi IGÉNYEK ÉS BEFOgAdó NEVELÉS... — -

Európai Ügynökség a Sajátos Nevelési Igényű Tanulókért és az Inkluzív Oktatásért, 2017. Az inkluziv oktatásban részt vevő tanulók iskolai sikerességének növelése: Összefoglaló zárójelentés. (V. J. Donnelly \& A. Kefallinou, eds) Odense (Dánia). https://www.europeanagency.org/sites/default/files/ra-summary-hu.pdf/ [Letöltve: 2020. 08. 26.]

Európai Ügynökség a Sajátos Nevelési Igényű Tanulókért és az Inkluzív Oktatásért, 2018. Az Európai Ügynökség Inkluziv Oktatás Statisztikai Rendszereit Vizsgáló Projektje: Kulcsfontosságú üzenetek és megállapitások (2014/2016). (A. Watkins, J. Ramberg \& LÉNÁRT A., eds) Odense (Dánia). https://www.european-agency.org/sites/default/files/ easie_key_messages_and_findings_2014-2016_hu_0.pdf/[Letöltve: 2020.08. 26.]

Európai Ügynökség a Sajátos Nevelési Igényű Tanulókért és az Inkluzív Oktatásért, 2018. Az inkluziv oktatási rendszer finanszírozási szakpolitikája: Összefoglaló zárójelentés. (E. Óskarsdóttir, A. Watkins \& S. Ebersold, eds) Odense (Dánia). https://www. european-agency.org/sites/default/files/FPIES-Summary-HU.pdf/ [Letöltve: 2020. 08. 26.]

European Agency for Special Needs and Inclusive Education, 2020. European Agency Statistics on Inclusive Education: 2018 Dataset Cross-Country Report. (J. Ramberg, A. LÉNÁRT $\&$ A. WatKins, eds) Odense (Denmark). https://www.european-agency.org/resources/ publications/european-agency-statistics-inclusive-education-2018-dataset-cross-country/ [Letöltve: 2020. 08. 26.]

HaLÁsz G. (2004) A sajátos nevelési igényü gyermekek oktatása: európai politikák és hazai kihívások. Új Pedagógiai Szemle, 2004. február. https://epa.oszk.hu/00000/ 00035/00079/2004-02-be-Halasz-Sajatos.html/ [Letöltve: 2020. 08. 26.]

ILLYÉs S. (2001) Az eszmény, a törvény, a tradíció és a feltételek a közoktatás megújulásában - különös tekintettel az ép és a fogyatékos gyermekek együttnevelésére. Új Pedagógiai Szemle, 2001/június-augusztus. https://ofi.oh.gov.hu/tudastar/eszmeny-torveny/ [Letöltve: 2020. 08. 26.]

KÁllaI G. (2018) Helyzetkép a sajátos nevelési igényü gyermekek együttneveléséröl. Előadás. Országos Neveléstudományi Konferencia.

Köpatakiné Mészáros M. (2009, ed.) Együttnevelés határon innen és túl. Budapest, Oktatáskutató és Fejlesztő Intézet.

LÁNyiné Engelmayer Á. (1993) A külföldi integrációs modellek tanulságai a hazai alkalmazás számára. In: CsÁNY Y. (ed.) Együttnevelés - speciális igényü tanulók az iskolában. Budapest, Iskolafejlesztési Alapítvány, OKI. pp. 11-21.

LÁnyiné Engelmayer Á. (2009) Intellektuális képességzavar és pszichés fejlödés. Budapest, Medicina Könyvkiadó.

LÁNyiné ENGelmayer Á. (2014) Változásban a pszichológiai és gyógypedagógiai diagnosztika. Neveléstudomány 2014/3. http://nevelestudomany.elte.hu/downloads/2014/ nevelestudomany_2014_3_33-52.pdf

Mile A. E. (2016) Gyógypedagógiai szakértelem, szerepek és kompetenciák az együttnevelés szolgálatában. Doktori disszertáció. Budapest, ELTE PPK NDI. https://ppk.elte.hu/file/ mile_aniko_eszter_dissz.pdf/ [Letöltve: 2020.08.26.]

National Education Systems - Eurydice. https://eacea.ec.europa.eu/national-policies/ eurydice/national-description_hu/ [Letöltve: 2020.08. 26.]

Papp G. \& Perlusz A. (2012) „....mindenképpen figyelni kell a folyamatokat és reagálni kell..." Kooperáció- és konkurenciafolyamatok a sajátos nevelési igényủ tanulókat ellátó intézményekben. In: Zászkaliczky P. (ed.) A társadalmi és iskolai integráció feltétele és korlátai. Budapest, ELTE Eötvös Kiadó. pp. 179-201. 
Schiffer Cs. (2012) „.+.az értelmét akkor kezdtem látni...” Kooperáció- és konkurenciafolyamatok a befogadó pedagógusok nézőpontjából. In: Zászkaliczky P. (ed.) A társadalmi és iskolai integráció feltétele és korlátai. Budapest, ELTE Eötvös Kiadó. pp. 227-263.

Speciális oktatás Európában (2003) Eds: Cor Meijer, Victoria Soriano \& Amanda Watrins. Európai Iroda a Speciális Oktatás Fejlesztéséért. http://epa.oszk.hu/00000/ 00035/00079/specialis.pdf/ [Letöltve: 2020. 08. 26.]

Szekeres Á., Perlusz A. \& Takács I. (2012) „...egy ideális világban csak így szabadna tanítani..." In: Zászkaliczky P. (ed.) A társadalmi és iskolai integráció feltétele és korlátai. Budapest, ELTE Eötvös Kiadó. pp. 201-227.

VARGÁné Mező L. (2004) Sajátos nevelési igényü tanulók együttneveléséröl pedagógusoknak, intézményvezetőknek. https://ofi.oh.gov.hu/tudastar/sajatos-nevelesi-igenyu/sajatosnevelesi-igenyu-090617-2/ [Letöltve: 2020. 08. 26.]

A cikk a Creative Commons Attribution 4.0 International License (https://creativecommons.org/licenses/ by/4.0/) feltételei szerint publikált Open Access közlemény, melynek szellemében a cikk bármilyen médiumban szabadon felhasználható, megosztható és újraközölhető, feltéve, hogy az eredeti szerző és a közlés helye, illetve a CC License linkje és az esetlegesen végrehajtott módosítások feltüntetésre kerülnek. (SID_1) 